\title{
THE ROLE OF AN URBAN FESTIVAL IN PUBLIC SPACE: CASE STUDY OF THE LIGHT MOVE FESTIVAL IN LÓDŹ
}

\begin{abstract}
The aim of this article is to examine the relationship between an urban festival and changes in the social and spatial-functional structures in a city. We analyze the Light Move Festival in Łódź as a case study, showing the use of light in emphasizing local identity and cultural heritage. Data for this study was collected by means of interviews with the festival's organizers. We also present data gathered in a survey conducted among the festival's participants in 2016. The results show the social-demographic structure of the respondents, frequency of participation and source of information. We present the correlation between the festival's spatial organization and the guidelines of the "Attractive Urban Spaces 2020+ Program" (Strategie przestrzennego rozwoju Łodzi 2020+ w ramach programu szczegółowego „Atrakcyjne przestrzenie miejskie $2020+$ +). The study presents the possibility to use an urban festival as a local potential for building sustainable social and spatial policy. With constant population outflow, such events may help to attract new residents and rebuild the city's image. It also creates an opportunity to test temporary traffic solutions and to familiarize the residents with them. Considering the revitalization actions undertaken by the city of Łódź, one might ask a question: What kind of impact does The Light Move Festival have on the city of Łódź?
\end{abstract}

Keywords Urban festival, public spaces, Light Move Festival, Łódź.

\section{Introduction}

In recent years there has been a visible increase in the awareness of culture's role in local urban and economic development. Urban festivals are a good way of creating a city's unique identity and experiencing its atmosphere (Robinson et al. 2004; Herrero et al. 2007; Johansson and Kociatkiewicz 2011; Del Barrio et al. 2012; Van Aalst and Van Melik 2012). They shape cultural heritage of a particular place (Gold and Gold 2005). Urban festivals located in well-known public spaces might 
encourage local community to connect, interact and discuss about the city. They may change the perception of the city's space, promote participation in culture and enhance local development (Evans 2009). Especially in recent years some post-socialist cities decided to change their image and economy by locating urban festivals in public spaces. They create a connection between cultures and places to rebuilt the sense of belonging as a part of urban regeneration (Cudny 2016).

Having considered changes in the post-socialist cities, we decided to take a multidisciplinary approach to this study in order to define the significance of organizing such a festival for the contemporary urban space. This article presents the Light Move Festival as a huge potential in the process of changing the perception of Łódź's image. Our aims include the following:

- to present the history and organizational structure and of the event,

- to describe the festival's last edition in 2016 in detail,

- to present the characteristics of the last edition,

- to define the outcomes of the festival for the urban space of Łódź.

\section{Methods}

Basic methods of the study included participant observation and semi-structured interview with the festival organizers. Another method was a survey concerning the festival's characteristics: social-demographic stratification of respondents, frequency of participation and sources of information. The survey was conducted in social media (the festival's Facebook page) among the participants $(n=333)$ of the Light Move Festival's fifth edition in 2016. The survey was available only online, therefore it may have caused some limitations in the representativeness of the sample. We also used the guidelines of the planning strategy of the new public spaces' system from “Attractive Urban Spaces 2020+ Program" (Strategie przestrzennego rozwoju Łodzi 2020+ w ramach programu szczegółowego ,Atrakcyjne przestrzenie miejskie 2020+") and spatial organization map of the Light Move Festival in 2015. The study allowed to present the use of the festival's spatial conditions for testing temporary solutions in public spaces.

\section{Festivals and public space in cities}

Urban festivals are currently becoming a crucial element of building the city's promotion policy and developing creative industry. Depending on the aim of an event, the city aspires to achieve certain economic or social results (Jamieson 2004). In his attempt to define the concept of a festival, Falassi states that it is "a sacred or profane time of celebration, marked by special observances" (Falassi 1987: 2). Because of their characteristics, types of festivals can be distinguished based on various criteria. In terms of location, festivals are divided into urban 
and rural (Falassi 1987). Another kind is the urban cultural heritage festival, which aims to present the spatial and cultural values of a certain place (Del Barrio et al. 2012). Among festivals relating to urban space we may distinguish 'place-bound' and 'placeless'. The first ones focus on the participation of the visitors in discovering authentic history of a place. The latter do not consider location as an important factor (MacLeod 2006).

Public space is define as a outdoor and freely accessible space for people conducive to social interaction or recreation (Cybriwsky 1999). Studies that take public space under examination are become an important factor in the local development of a city. They concern the influence of attractiveness and availability of such spaces on the city's functioning (Pasaogullari, Doratli 2004; Vasilevska et. al. 2014), as well as their impact on user's well-being (Villanueva et. al. 2015), and on the increase in local social interactions (Langegger 2014).

The space's physical availability may be temporarily limited due to safety conditions or its organization (Lorens, Martyniuk-Pęczek 2010). That is why public spaces play a crucial role in a wide spectrum of social interactions (Gehl 2001). Research conducted since the 1960' shows that cities' inhabitants experience the lack of public spaces in daily life (Jacobs 1961). Today public spaces consist of loosely connected pieces and functions, ever so often with no palpable connection to the city (Dymnicka 2008). A coherent system of public spaces guarantees their availability and increase in the attractiveness of the places focused primarily on the inhabitants. Additionally, it may contribute to the revitalization of degraded terrains, implementing new spatial-functional connections that allow to obliterate the existing barriers of exclusion and conflict (McGuirk 2014).

Festivals embedded in a public space, oriented towards local heritage and culture encourage to rediscover the city. On the one hand such events enrich the city's cultural offer and hence attract tourists (Evans 2001), building its image and visibility. They can also provide a valid incentive for visitors to remain in a city for a longer time (Getz 1991). On the other hand such festivals create an opportunity for the local community to benefit from the cultural offer. During a festival, inhabitants are encouraged to observe the changes in the space of their city.

"Place-bound" festivals provoke discussion about public spaces and enhance the sense of responsibility and attachment. Cities in a demographic and economic crisis undergoing revitalization are particularly searching for such an effect. Especially shrinking cities with a constantly decreasing number of inhabitants and experiencing economic problems search for ways to change their image. One of the solutions is to develop a conscious cultural strategy focused on authenticity and uniqueness of the place's cultural heritage (Young, Kaczmarek 2008). According to such attitude, an urban festival's intervention in public space may enhance the positive change in space's perception by its users. In many cases an urban festival 
becomes an inherent factor supporting revitalization and development strategies (Quinn 2005). Festival's social functions include escape from daily routine, social interactions and opportunity to meet with one's significant others (Crompton, McKay 1997). Cities endangered by population decrease may especially benefit from a festival that influences the positive perception and attachment, as it may attract new inhabitants. It may also become an incentive to execute public policy in terms of eliminating alienation and rebuilding social bonds (Hughes 1999). Additionally, improvement in atmosphere and residents' quality of life has a positive effect on the tourists' perception of a city (Rouba 2010). On the other hand, improvement in tourism may prove to be troublesome, causing congestion, noise and traffic problems. In some cases it can lead to gentrification, i.e. the exchange of local community (Zukin 1996; Martin 2005).

\section{The aspects of illumination in urban regeneration of Lódź}

In the last decade many cities have proved that light has a positive impact on urban identity. The strategy of improving the quality of lighting systems is focused on ensuring residents' security and exposing the spatial arrangements of different districts, monuments, and streets. The city of Lyon in France organized "Plan Lumiere" since the 1990s to create a professional approach to lighting and illumination. One of the main assumptions of this strategy is consistently implemented in a five day-long festival of light called "Fête des Lumières". Lyon's festival has become an inspiration for many other cities in the world: Ghent's "Licht Festiwal" in Belgium, Berlin's "Festival des Lichtes" in Germany, Tokio's "Hotaru Festival" in Japan, and other members associated in the Lighting Urban Community International. The example of the Lyon festival was the initial inspiration for a few cities in Poland, including Łódź.

In the $19^{\text {th }}$ century, Łódź was the most important mono-functional industrial city in Poland due to its textile industry. The industrial function of the city was a key factor increasingly influencing its architectural and spatial form. The political turn of 1989 in Poland affected Łódź by the collapse of the industry and caused serious economic problems characteristic for a post-socialist city (Czepczyński 2008). Still diminishing population and devastating economic conditions are typical for shrinking cities' situation (Martinez-Fernandez et. al. 2012). Therefore, some post-socialist cities focus on developing identity based on culture and art as elements of stemming decline. Urban events as a part of culture-led strategies may help reshape the image of urban areas inviting new residents and creative industries (Gibson et. al. 2012). To reduce the negative influence, municipal authorities created a new idea of the city advertised with the slogan "Lódź creating", with potential to increase investment in creative industries. Simultaneously, they led the integrated urban regeneration program in crucial degraded areas. The value 
of the city's unique post-industrial architecture originating in the $19^{\text {th }}$ century has meaning in contemporary urban identity formation (Young, Kaczmarek 2008). To highlight the post-industrial image by using light illumination and video mapping, the nonprofit organization "Lux Pro Monumentis" (Latin for 'light for buildings') organizes The Light Move Festival in Łódź since 2011. Festival's financing is based upon a cooperation with the culture partners, sponsors and municipalities in the form of public subsidies and grants.

The main purpose of this urban festival is to find the way to revive the urban space by using culture and art. Events are met with great interest from the residents and tourists due to unique architecture and free, open participation form. The number of participants increased from 2011 to 2016, indicating the festival's development and the increase of satisfaction (Table 1). During the three days of The Light Move Festival, residential and post-industrial buildings including well-known public spaces are illuminated.

Table 1

Characteristics of the Light Move Festival

\begin{tabular}{cc}
\hline Factor & Light Move Festival \\
\hline Location & Łódź \\
\hline Schedule & 3 days in October \\
\hline Year of origin & 2011 \\
\hline Organization & $\begin{array}{c}\text { since 2011: the nonprofit organization } \\
\text { "Lux Pro Monumentis" }\end{array}$ \\
\hline Municipal subsidies & about 280560 $€$ per year $(1200000 \mathrm{zt})$ \\
\hline Amount of participants in & 45000 \\
\hline 2011 & 97000 \\
\hline 2012 & 200000 \\
\hline 2013 & 350000 \\
\hline 2014 & 550000 \\
\hline 2015 & 640000 \\
\hline 2016 &
\end{tabular}

Source: own elaboration based on LMF organization

Artistic use of light during the festival is expressed by movement, projection, animation, kinetic art, sound and color. The light is also associated with the film industry, which is very characteristic for Łódź as a film city. The festival enables the development of young artists from the Polish National Film, Television and Theatre 
School and the Academy of Fine Arts by showing their art projects (Szwed 2012). The program of urban regeneration focused at first just on Piotrkowska street as the center of cultural, social and commercial life of the old Łódź. According to the city's strategy, main illuminations of the festival were presented in Piotrkowska street, representative and one of the longest high streets in Europe. In 2015 the festival also aimed to highlight the industrial character of the city and occurring public spaces. The area of the festival has been expanded to the revitalized zone of the former power plant - EC1 (Photo 1). The revival of EC1 and the construction of the new "Lódź Fabryczna" railway station are priority investments in creation of the main revival project - the New Centre of Łódź. In 2013 EC1 building was transformed into a cultural center with a library, a planetarium and a recording studio for film music (Gałuszka 2010). Consequently, the area of EC1 was chosen as the official location of the festival's opening event. It thus encourages to visit the renewed, post-industrial part of the city. One of the additional events was the conference: "Light and color in architecture and public spaces - about a conscious creation of the city's image". Speeches focused on the issue of illumination as part of the revitalization of urban spaces and possible sources of financing such investments. The organizers decided to cooperate with Philips company, which focuses on electronics and lighting. From that moment on, the company supported the execution of illuminations based on their equipment and artistic vision. It may be a first step to sustainable approach to lighting system in the city. Additionally in 2016, the organizers of the festival, "Lux Pro Monumentis" Foundation, introduced a series of workshops on pro-ecological illumination of the urban space entitled "Light that you breathe in". The aim of the workshops was to design illumination for public spaces - buildings, nature and open space.

The assumption of the festival in Łódź is to emphasize the architectural character of the city by means of an illuminations. Projections are set in the city center on buildings, most important parks and squares - Sienkiewicz Park, Rubinstein passage, EC1 area (Photo 2). Because of communication needs, traffic was organized differently in the festival's area (Fig. 1). The main net of streets in the city center was excluded from car traffic. It allowed the festival's participants to move freely and promoted making urban space available to pedestrians. It is a complementary way of meeting the city's mobility policy with regard to traffic limitation and improvement of the public spaces' quality. A new bus line "LMF" between Kościuszki street and Łódź Kaliska Station was introduced in order to provide additional transportation. Most illuminations were spatially arranged in Sienkiewicza park, EC1 area and the event's axis - Piotrowska street. As Fig. 1 shows, the location of the illuminations coincides with the new public spaces system. Simultaneously the whole city center functions as a revitalization area. During three days, the Light Move Festival allows the temporary traffic and spatial solutions to be tested. Additionally, illuminations in the city center invite festival's participants to rediscover the city's space. 


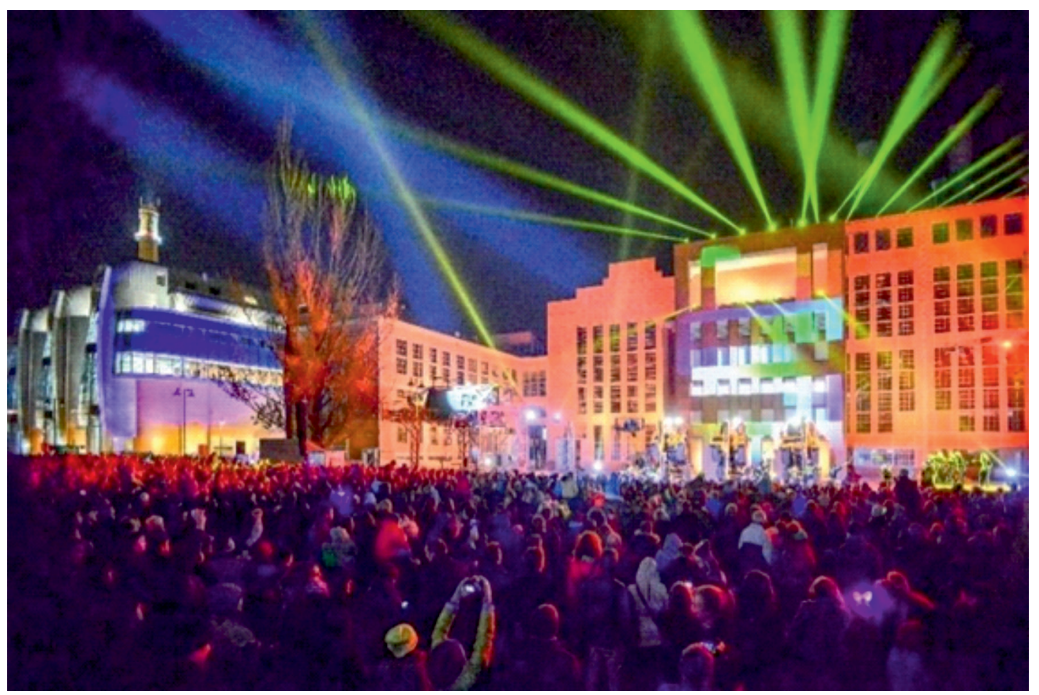

Photo 1. Portions of illumination of the EC1 buildings at the Targowa street Source: LMF organization

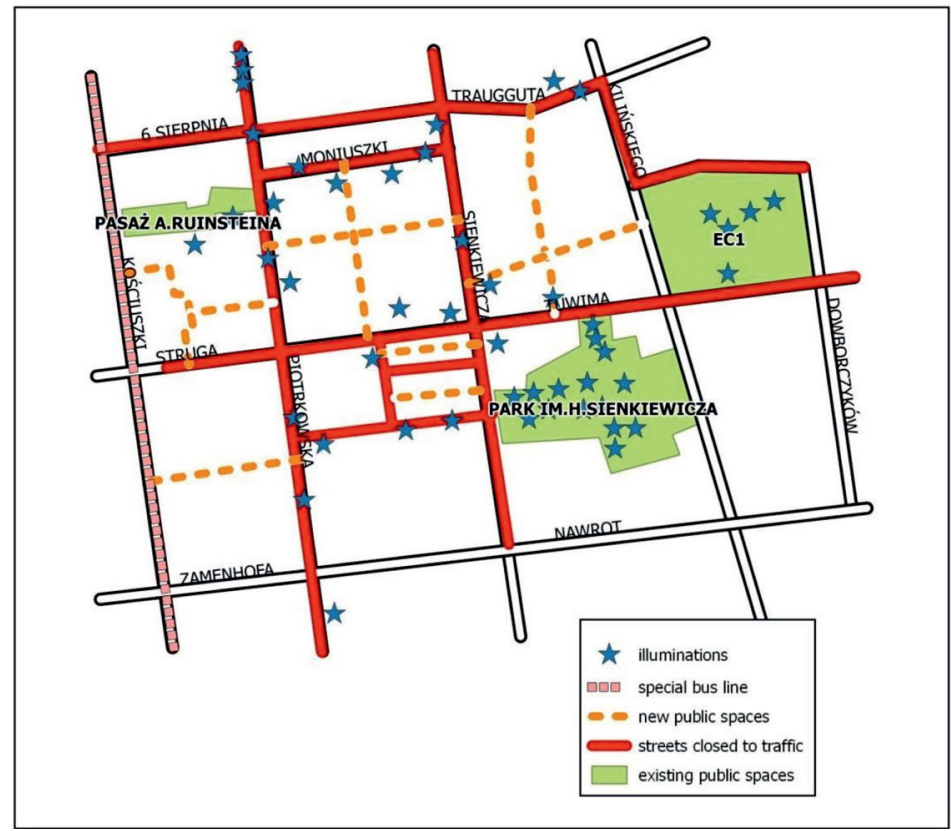

Fig. 1. Spatial organization of the Light Move Festival in 2015 and planning strategy of the new public spaces' system

Source: own elaboration based on LMF organization in 2015 and from Strategia przestrzennego rozwoju Łodzi 2020+, program szczegółowy „,Atrakcyjne przestrzenie miejskie 2020+” 


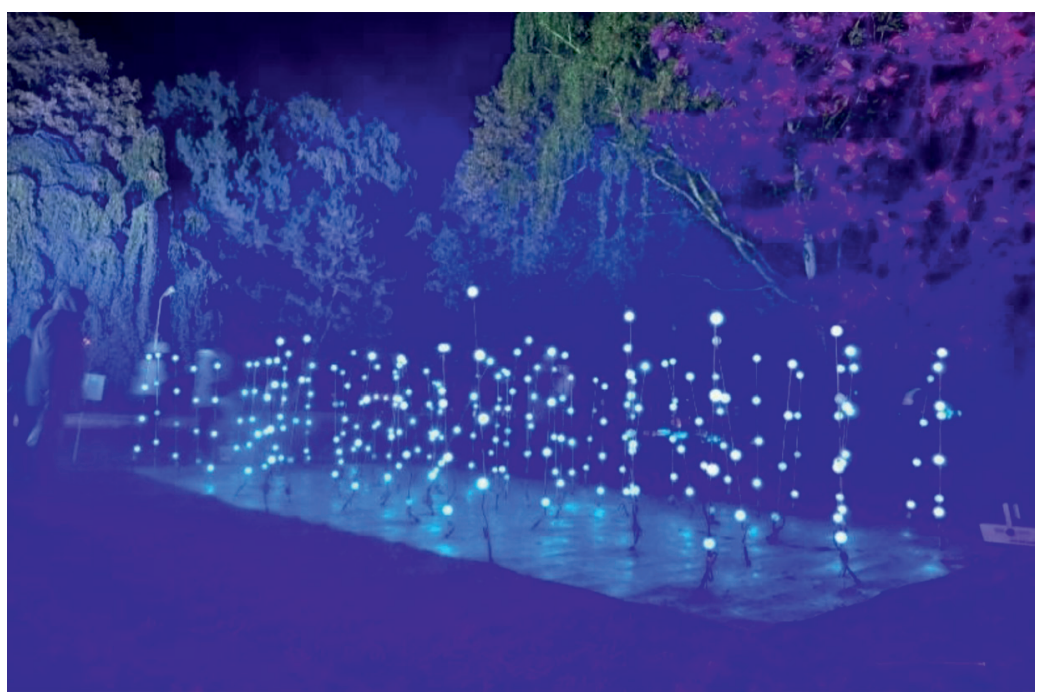

Photo 2. Aqua Olimpia installation in the Sienkiewicz Park

Source: LMF organization

\section{Characteristics of the Light Move Festival survey respondents in 2016}

The article presents the results of a survey conducted on Facebook page among the participants of the Light Move Festival's fifth edition in October 2016. The aim of the study was to identify the target group of the event's participants and their opinion about the festival. The sample consisted of 333 respondents (Table 2). The majority of respondents were women $(68.8 \%)$. More than half of respondents were young people, between 20 and 30 years old (50.2\%), and the smallest group were people aged more than 60 . The vast majority of respondents declared to be residents of Łódź (63.7\%). We examined the frequency of participation in the event and found out that most respondents took part in the festival for the second or third time $(39 \%)$. The main source of information about the event was the Internet $(41.4 \%)$ and social media $(27.6 \%)$.

The survey showed that the majority of respondents were young people, women in particular, who live in Łódź. With regard to the constant population outflow, the festival may become an attractive cultural potential, keeping young people in the city. The vast majority of the survey respondents are the residents of Łódź, which proves that Light Move Festival is still a rather local event. In this way it can performs social and cultural functions and have a positive impact on the local community. A large number of respondents attended the festival's previous editions, which suggests that the degree of satisfaction with the event is rising. The main sources of information about the festival included the Internet 
Table 2

Characteristics of the Light Move Festival survey respondents in 2016

\begin{tabular}{|c|c|}
\hline \multicolumn{2}{|l|}{$(2016) n=333$} \\
\hline \multicolumn{2}{|l|}{ Gender (percent) } \\
\hline Female & 68.8 \\
\hline Male & 31.2 \\
\hline \multicolumn{2}{|l|}{ Age } \\
\hline Under 20 & 8.7 \\
\hline $20-30$ & 50.2 \\
\hline $31-40$ & 25.5 \\
\hline $41-50$ & 12.0 \\
\hline $51-60$ & 2.7 \\
\hline More 60 & 0.9 \\
\hline \multicolumn{2}{|l|}{ Residence (percent) } \\
\hline Łódź & 63.7 \\
\hline Łódź voivodeship & 16.8 \\
\hline Neighboring voivodeship & 6.9 \\
\hline Poland & 11.41 \\
\hline Abroad & 1.2 \\
\hline \multicolumn{2}{|c|}{ Frequency of participation (percent) } \\
\hline First time & 18.32 \\
\hline Second-third time & 39.04 \\
\hline Fourth-fifth time & 26.43 \\
\hline All of the editions & 16.22 \\
\hline \multicolumn{2}{|c|}{ Source of information about the festival (percent) } \\
\hline Traditional press & 2.70 \\
\hline Radio & 0.30 \\
\hline Television & 0.60 \\
\hline Internet & 41.44 \\
\hline Social media & 27.63 \\
\hline Friends/family & 21.02 \\
\hline External media (posters, citylights, billboards) & 3.60 \\
\hline Other & 2.71 \\
\hline
\end{tabular}

Source: own elaboration based on LMF survey. 
and social media. The study were conducted using social media and that excluded respondents without access to the Internet or elder people. For the future studies, it is therefore necessary to conduct survey among participants during Festival. It is also a need to extend the festival promotion sources to attract other groups of residents.

\section{Conclusion}

The Light Move Festival focuses on the use of light in presenting the post-industrial architecture and public spaces, influencing the development of city of Łódź's positive image. It is particularly important in the context of shrinking cities, where the number of residents is decreasing. Festival may become a invitation for new residents, especially young people. Increasing interest in the event may not only enhance the touristic value, but also boost investments in space. That is why it often becomes a part of a city's development strategy and revitalization plans (Morgan 2007). The Light Move Festival should constitute a frame for the execution of the present revitalization plan, concerning residents' activation and improvement of the city's image. It should create potential to engage local community and change the perception of the present space. For instance, the light festival in Lyon provides for active engagement of the residents in creating their own light installations, becoming the tool for creating social unity (Zienowicz, Podhajska 2014). In the long term the festival could support the revitalization of city of Łódź through culture, promotion of local architecture and help to build a sense of pride among the residents. It bring them closer to the city cultural offer and create perspectives for social interactions. That is why, it is hard not to agree with Bailey's claim (Bailey et al. 2004: 47), that a festival should be better inscribed into a city's local context.

Urban festivals also allow the temporary use of public space. It may become a chance to test temporary changes of mobility. It seems crucial to establish a link between a festival and a city's planning and revitalization policies. Urban planners and city officials responsible for promotion should use the Light Move Festival as a potential for implementing changes in public spaces' organization, building promotion and social relations. The conducted studies may help in: the complex use of social and spatial dimensions of illuminations to enhance the city image, the development of a city's sustainable lighting policy and the revitalization focused on giving the public space back to the residents. 


\section{LITERATURE}

Bailey C. et. al., 2004, Culture-led urban regeneration and the revitalization of identities in Newcastle, Gateshead and the North East of England, „International Journal of Cultural Policy", $10(1)$ : 47-65.

Crompton J., McKay S., 1997, Motives of visitors attending festival events, „Annals of Tourism Research", 24: 425-439.

Cudny W., 2016, Festivalisation of Urban Spaces, Factors, Processes and Effects, Springer International Publishing, Switzerland.

Cybriwsky R., 1999, Changing patterns of urban public space Observations and assessments from the Tokyo and New York metropolitan areas, „Cities”, 16(4).

Czepczyński M., 2008, Cultural Landscapes of Post-Socialist Cities. Representation of Powers and Needs, Ashgate, Hampshire,

Del Barrio M.J., Devesa M., Herrero L.C., 2012, Evaluating intangible cultural heritage: The case of cultural festivals City, „Culture and Society”, 3: 235-244.

Dymnicka M., 2008, Fragmentaryzacja przestrzeni publicznej - próby rekompozycji, „Studia Regionalne i Lokalne”, 3 (33).

Evans G., 2001, Cultural planning, an urban renaissance, Routledge, London.

Evans G., 2009, Creative cities, creative spaces and urban policy, „Urban Studies”, 46: $1003-1040$.

Falassi A. (red.), 1987, Festival: Definition and Morphology. Time Out of Time: Essays on the Festival, University of New Mexico Press, Albuquerque: 1-10.

Gałuszka J., 2010, Wokół nowego centrum Łodzi, EC1 Łódź - Miasto Kultury, Łódź.

Gehl J., 2001, Life Between Buildings, The Danish Architectural Press, Copenhagen.

Getz D., 1991, Festivals, Special Events and Tourism, Van Norstrand Reinhold, New York.

Gibson C., Gallan B., Warren A., 2012, Engaging creative communities in an industrial city setting: A question of enclosure, ,International Journal of Community Research and Engagement", 5, Gateways: 1-15.

Gold J.R., Gold M.M., 2005, Cities of Culture: Staging International Festivals and the Urban Agenda, Burlington, Ashgate, Warsaw: 1851-2000.

Herrero L.C., Sanz J.A., Devesa M., Bedate A., del Barrio M.J., 2007, Economic impact and social performance of cultural macrofestivals, Cultural Tourism: Global and Local Perspectives: $303-323$.

Hughes G., 1999, Urban revitalization: the use offestival time strategies, „Leisure Studies”, 18(2): 119-135.

Jacobs J., 1961, The Death and Life of Great American Cities, The Modern Library, New York.

Jamieson K., 2004, The festival gaze and its boundaries, „Space \& Culture”, 7(1): 64-75.

Johansson M., Kociatkiewicz J., 2011, City festivals: Creativity and control in staged urban experiences, „European Urban and Regional Studies”, 18: 392-405.

Langegger S., 2014, Reprint of Emergent public space: Sustaining Chicano culture in North Denver, „Cities”, 40.

Lorens P., Martyniuk-Pęczek J., 2010, Problemy kształtowania przestrzeni publicznych, Wydawnictwo Urbanista, Gdańsk. 
MacLeod N., 2006, The placeless festival: Identity and place in the post-modern festival, [in:] Picard D., Robinson M. (eds.), Festivals, Tourism and Social Change: Remaking Worlds, Channel View Publications, Clevedon: 222-237.

Martin G.P., 2005, Narratives great and small: neighbourhood change, place and identity in Notting Hill, ,International Journal of Urban and Regional Research”, 29(1): 67-88.

Martinez-Fernandez C. et al., 2012, Shrinking cities: Urban challenges of globalization, „International Journal of Urban and Regional Research”, 36(2): 213-225.

McGuirk J., 2014, Radykalne miasta. Przez Amerykę Lacińska w poszukiwaniu nowej architektury, Fundacja Bęc Zmiana.

Morgan M., 2007, Festival Spaces and the Visitor Experience, [in:] Casado-Diaz M., Everett S., Wilson J. (eds.), Social and Cultural Change: Making Space(s) for Leisure and Tourism, Lesiure Studies Association, Eastbourne, UK: 113-130.

Pasaogullari N., Doratli N., 2004, Measuring accessibility and utilization of public spaces in Famagusta, „Cities”, 21 (3).

Quinn B., 2005, Changing festival places: insights from Galway, „Social and Cultural Geography", 6(2).

Quinn B., 2005, Arts festivals and the city, „Urban Studies”, 42 (5-6): 927-943.

Robinson M., Picard D., Long P., 2004, Festival tourism: producing, translating, and consuming expressions of culture (s), „Event Management”, 8(4): 187-242.

Rouba R., 2010, Hotel Services in Historic Residences - the Effect on Landscape, ŁTN, Łódź.

Szwed J., 2012, Współczesne tendencje i możliwości wykorzystania oświetlenia zewnętrznego w promocji i rozwoju miasta, „Festiwal Światła, Przestrzeń i Forma”, 18: 227-240.

Uchwała nr LV/1146/13 Rady Miejskiej w Łodzi z dnia 16 stycznia 2013 roku $w$ sprawie Strategii przestrzennego rozwoju Łodzi 2020+, program szczegółowy „Atrakcyjne przestrzenie miejskie 2020+".

Van Aalst I., van Melik R., 2012, City festivals and urban development: does place matter?, „European Urban and Regional Studies”, 19(2): 195-206.

Vasilevska L., Vranic P., Marinkovic A., 2014, The effects of changes to the post-socialist urban planning framework on public open spaces in multi-story housing areas: A view from Nis, Serbia, „Cities”, 36.

Villanueva K., Badland H., Hooper P., Koohsari M.J., Mavoa S., Davern M., Giles-Corti B., 2015 , Developing indicators of public open space to promote health and wellbeing in communities, „Applied Geography”, 57.

Young C., Kaczmarek S., 2008, The socialist past and postsocialist urban identity in Central and Eastern Europe. The case of Łódź, Poland, „European Urban and Regional Studies", 15 (1): 53-70.

Zienowicz M., Podhajska E., 2014, Kierunki, strategie i perspektywy współczesnej iluminacji i oświetlenia miast na przykładzie Lyonu, „Architectus”, 2 (38): 69-78.

Zukin S., 1996, Space \& symbols in an age of decline, [in:] King A. (eds.), Re-presenting the city: Ethnicity, capital and culture in the $21^{\text {st }}$ century metropolis, New York University Press, New York: 233-242. 


\section{ROLA FESTIWALU MIEJSKIEGO W PRZESTRZENI PUBLICZNEJ NA PRZYKLADZIE LIGHT MOVE FESTIVAL W LODZI}

Zarys treści Celem artykułu jest poznanie zależności pomiędzy miejskim festiwalem a przemianami struktury przestrzenno-funkcjonalnej i społecznej w mieście. Jako studium przypadku wskazano festiwal wykorzystujący światło do podkreślenia lokalnej tożsamości i dziedzictwa kulturowego - Light Move Festival w Lodzi. W opracowaniu wykorzystano informacje pozyskane $\mathrm{z}$ wywiadów prowadzonych $\mathrm{z}$ organizatorami festiwalu. Zaprezentowano dane zgromadzone na podstawie ankiety prowadzonej wśród uczestników festiwalu w 2016 roku. Wyniki pokazują społeczno-demograficzną strukturę ankietowanych, częstotliwość uczestnictwa oraz źródła informacji o wydarzeniu. Za pomocą mapy poglądowej zaprezentowano zależność pomiędzy przestrzenną organizacji festiwalu a założeniami Strategii przestrzennego rozwoju Łodzi $2020+$ w ramach programu szczególowego „Atrakcyjne przestrzenie miejskie 2020+". Badanie wskazuje na możliwość wykorzystania festiwalu miejskiego jako lokalnego potencjału, wartościowego w budowaniu zrównoważonej polityki społecznej oraz przestrzennej. Wobec spadku liczby ludności w Lodzi, festiwal może wspierać promowanie miasta wśród potencjalnych nowych mieszkańców. Stwarza szanse na przetestowanie tymczasowych rozwiązań komunikacyjnych w przestrzeni oraz oswojenie z nimi mieszkańców. Mając na uwadze działania rewitalizacyjne prowadzone w mieście Łódź, można zadać pytanie: jaki wpływ na społeczność i przestrzeń miasta Łodzi ma festiwal światła - Light Move Festival?

Stowa kluczowe Festiwal miejski, przestrzeń publiczna, Light Move Festival, Łódź.

Mgr Magdalena Miśkowiec Instytut Rozwoju Miast w Krakowie e-mail: mmiskowiec@irm.krakow.pl

Zakład Rozwoju Regionalnego Instytut Geografii i Gospodarki Przestrzennej

Wydział Geografii i Geologii

Uniwersytet Jagielloński e-mail: magda.miskowiec@doctoral.uj.edu.pl 